\title{
ポリカーボネート樹脂の応力ー歪み曲線に及ぼす 電子線照射の影響
}

\section{高橋辰也* 森下忠衛西義武}

東海大学工学部材料科学科

J. Japan Inst. Metals, Vol. 69, No. 8 (2005), pp. 759-762

(C) 2005 The Japan Institute of Metals

\section{Effect of Electron Beam Irradiation on Stress-Strain Curves of Tensile Test of Polycarbonate Resin}

Tatsuya Takahashi*, Tadae Morishita and Yoshitake Nishi

Department of Materials Science, School of Engineering, Tokai University, Hiratsuka 259-1292

Influences of electron beam irradiation on stress-strain curves of tensile test were studied for polycarbonate resin. The electron beam (EB) irradiation enhanced the tensile strength and ductility. The maximum values were found at $0.2 \mathrm{MGy}$ of EB-irradiation. On the other hand, excess EB irradiation decreased the tensile fracture stress and ductility. To discuss the effect of electron beam on tensile strength and ductility, the dangling bonds formation was evaluated by ESR signals. The enhancements of ductility and fracture stress can be explained by stress relaxation induced by increase in density of dangling bonds.

(Received April 25, 2005; Accepted July 25, 2005)

Keywords: polycarbonate resin, electron beam, fracture stress, ductility, electron spin resonance

\section{1. 緒言}

現在の生活において, 高強度, 低コストで加工性に優れて いるプラスチック材料は必要不可欠な材料である. その使用 用途々しては土木建設材料, 精密機械材料から航空機用空材 料の構造材料としてだけではなく幅広い分野で応用されてい る.これらのことから機械的性質を向上させることはさらな る産業分野の発達につながり, 常に要求されている. ところ で, 低エネルギーの電子線照射は高分子材料の耐摩耗性や光 沢の向上に工業的に広く使用されている. 本研究グループに 拈いては炭素繊維， C/C, CFRP における強勒化 ${ }^{1-3)}$, セラミ ックス材料においては脆性改善 ${ }^{4)}$, ぬれ性の向上 ${ }^{5)}$, さら に, 高分子材料においては防量効果発現 6 に関する表面改質 を報告している. 一方, 建材, 機械材料や空材料には引張強 度や衝撃強度に代表される機械的性質に優れていることが求 められる. ポリカーボネート樹脂はこれらの特性に優れてい るため, 多くの分野で使用される. そこで本研究では, 幅広 い分野で使用されているポリカーボネート樹脂に電子線照射 処理を行い, 機械的性質として引張試験を用いて電子線によ る応力一歪み曲線に及ぼす影響について検討を行った。

\footnotetext{
* 現在 : 東海大学院生 (Graduate Student, Tokai University)
}

\section{2. 実 験 方 法}

\section{1 電子線照射処理}

電子線照射処理装置は Fig. 1 に示すエレクトロカーテン プロセッサー(岩崎電気侏 Type CB175/15/180L, 東京)を 用いた。この装置の特徵は, 大気圧下の窒素ガス気流中で, 電子線照射を行える点である. また, 照射処理はコンベアー 上で短時間に電子線を照射することから表面温度の上昇を極 力抑えることができる. 本研究での電子線照射処理条件は加 速電圧 $170 \mathrm{kV}$, 照射電流 0.5, 1.0, 1.5, $2.0 \mathrm{mA，コンベアー}$ スピード $9.56 \mathrm{~m} / \mathrm{min}$, 電子線照射処理雾囲気は酸素濃度 $400 \mathrm{ppm}$ 以下の窒素雾囲気である。 また電子線照射線量は 照射回数抢よび照射電流を変化させることで制御した。な お，照射線量の校正は RCD ナイロン線量計(FWT-60-00 : 線量フィルム, FWT-92D : 吸光度測定用専用リーダー, FAR WEST TECHNOLOGY, 米国)を用いた. また, 電子 線照射処理による電子線の侵入深さ $D_{\mathrm{epth}}(\mu \mathrm{m})$ の算出は式 ( 1 ) により行った7).

$$
D_{\text {epth }} \cdot \rho=66.7 V^{5 / 3}
$$

式中の $V$ は加速電圧 $(\mathrm{kV}), \rho$ は密度 $\left(\mathrm{kg} / \mathrm{m}^{3}\right)$ である.

$\mathrm{Ti}$ 薄板と窒素ガス層を電子線が通過する時に非弾性散乱 による運動エネルギーの減衰がある. 本研究において, 試料 に対する電子線の侵入深さを求める場合, 電子の電子線源か ら試料に到達するまでの, 電子の運動エネルギーの減衰を考 慮する必要がある。本装置の電子線照射空は Ti 製 (4540 


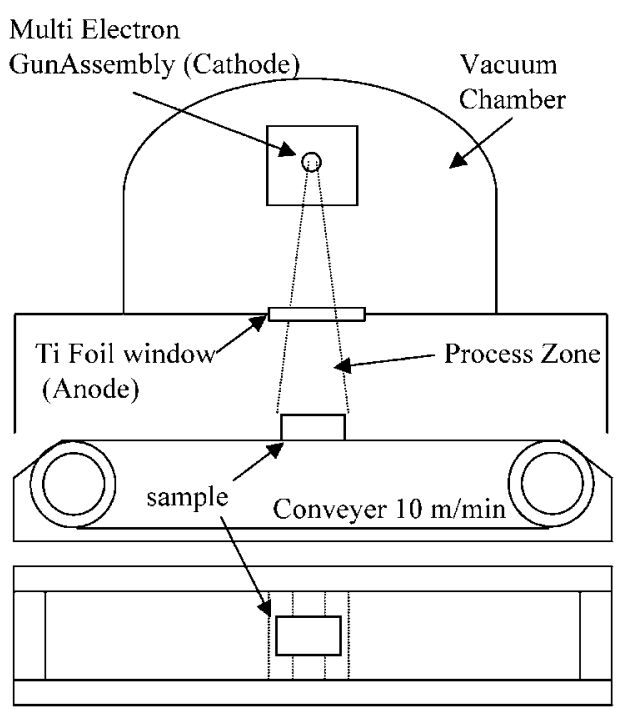

Fig. 1 Schematic diagram of electron curtain processor.

$\left.\mathrm{kg} / \mathrm{m}^{3}\right)$ であり，厚さが $10 \mu \mathrm{m}$ の薄板を使用している．また 照射空から試料までの距離は約 $30 \mu \mathrm{m}$ であり，照射空から 試料の間は大気圧の窒素ガス $\left(1.13 \mathrm{~kg} / \mathrm{m}^{3}\right)$ が存在してい る.このことから, 式 (1)を基に試料表面での電子の平均 運動エネルギーを求めると $128 \mathrm{keV}$ となる. 今回用いたポ リカーボネート樹脂の密度 $\rho$ は $1200 \mathrm{~kg} / \mathrm{m}^{3}$ であることから 電子線の侵入深さは $0.185 \mathrm{~mm}\left(1.85 \times 10^{-4} \mathrm{~m}\right)$ である. とこ ろで, 本研究での試料の厚さは $2.0 \mathrm{~mm}$ であるため, 電子線 は表面層のみ照射された状態である.

\section{2 引張試験}

引張試験の試料片は JIS の K7113-1995 の 1 号型小型試 験片を参考に機械加工を用いて作製を行った。試料形状は幅 $10.0 \mathrm{~mm}$, 厚さ $2.0 \mathrm{~mm}$ ，全長 $75.0 \mathrm{~mm}$ ，評点間距離 30.0 $\mathrm{mm}$ である. 引張強度の測定にはインストロン(3367 model: Instron Company， 米国）を用いた。引張試験の測定は 21.5 $\pm 2.0^{\circ} \mathrm{C}$ の雰囲気で行った。また引張試験速度はJISの K7113-1995 より $1 \mathrm{~mm} / \mathrm{min}$ とした.

\section{3 電子スピン共鳴装置}

ダングリングボンドの測定には電子スピン共鳴装置 (ESR) (JES-FA100：日本電子陎，東京)を用いた。使用し たマイクロ波は X バンドであり，磁場精度は $5 \mu \mathrm{T}$ である.

\section{3. 結 果}

\subsection{SEM による破断面観察}

Fig. 2 にポリカーボネート樹脂の引張試験による破断面の SEM 像を示す。それぞれ (a)は電子線照射前の引張破断 面, (b) は電子線照射後 (0.0216 MGy) の引張破断面であ る.この写真より, 引張試験の破断は表面から破断すること が確認できた。また，この写真からポリカーボネート樹脂の 破壊は延性破壊であることが確認できた。一方で，電子線照 射処理による破断の起点の变化においては，特に電子線の影

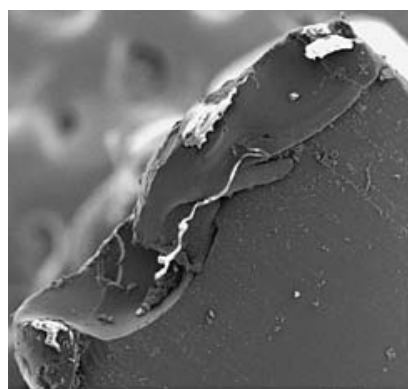

(a) Before $\mathrm{EB}$

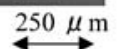

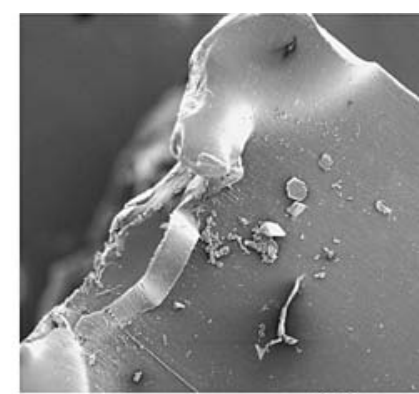

(b) After EB $\stackrel{250 \mu \mathrm{m}}{\longleftrightarrow}$
Fig. 2 SEM micrographs before (a) and after electron beam (b) of polycarbonate.

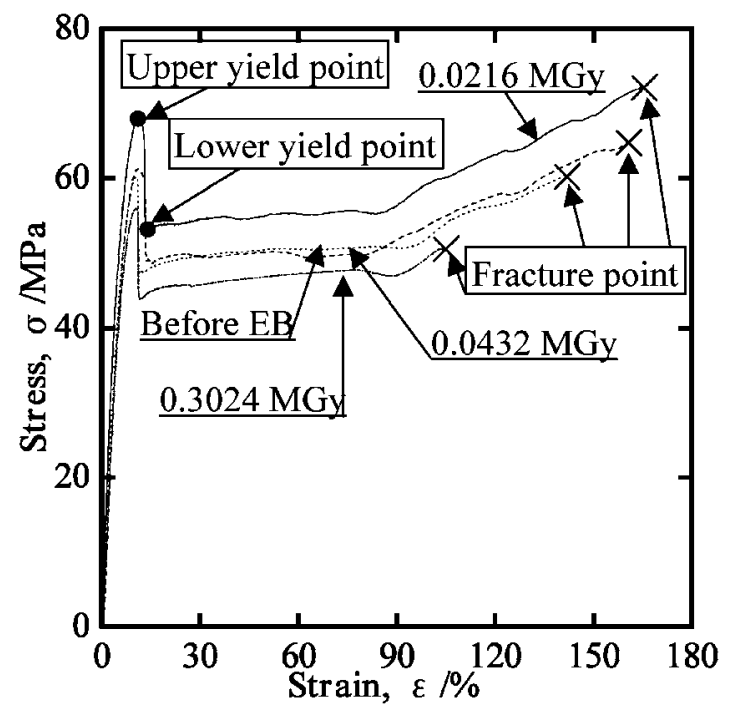

Fig. 3 Stress-strain curves of polycarbonate resin at different electron beam irradiation dose.

響を及ぼさない事が分かった。

\section{2 応力-歪み曲線とその電子線照射の影響}

Fig. 3 に電子線照射したポリカーボネート樹脂の応力ー歪 み曲線を示す。この図より, 0.0216 MGy 以下の低照射線量 に抢いて曲線の変形抵抗が増大し, 破断するまでのひずみが 増大し, 延性の向上を確認した. 一般の軟鋼の応力一歪久曲 線に形状が似ているので, 変形抵抗の特徵的な点を, 下降伏 強度 $\left(\sigma_{\mathrm{Y}}\right)$, 破断強度 $\left(\sigma_{\mathrm{F}}\right)$, 破断ひずみ( 延性 : $\left.\varepsilon_{\mathrm{f}}\right)$ とし, 各 因子の電子線照射の影響について検討を行った.

Fig. 4 にはポリカーボネート樹脂に抢ける電子線照射に抢 ける $\sigma_{\mathrm{U}}, \sigma_{\mathrm{Y}}, \sigma_{\mathrm{F}}$ の関係を示す。この図より, 電子線照射は ポリカーボネート樹脂の各応力值を増大し， 0.02 (精確には 0.0216) MGy の電子線照射量で最大值を示すことを見出し た.一方，このことから低電子線照射によりポリカーボネー 卜樹脂の引張強度の向上が見られた.

一方，過剰な電子線照射により各応力は低下し，0.2 MGy 以上の照射量における各応力の值は照射前の值以下になるこ とを確認した。

Fig. 5 には電子線照射に伴う破断ひずみの変化を示す．応 力と同じように電子線照射により破断ひずみが増大し， 0.02 


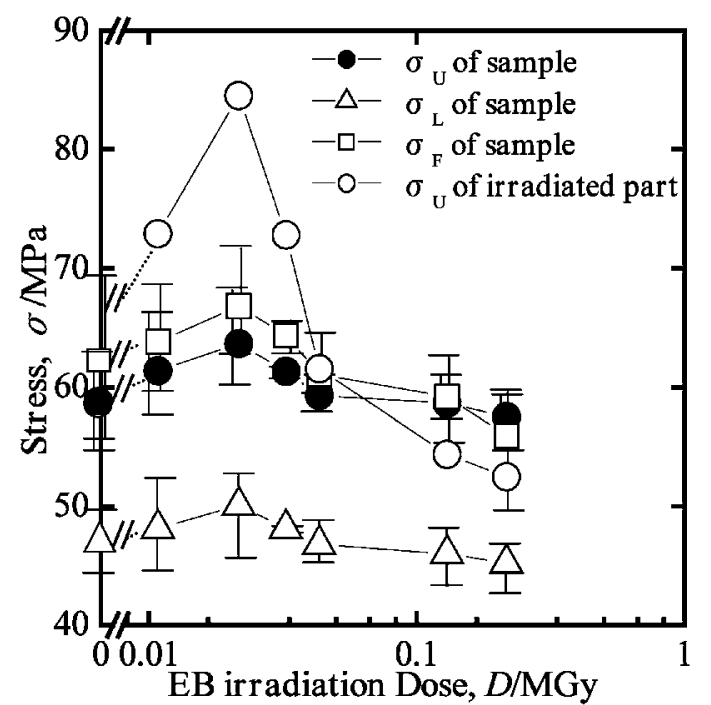

Fig. 4 Changes in upper yield stress $\left(\sigma_{\mathrm{U}}\right)$, lower yield stress $\left(\sigma_{\mathrm{L}}\right)$ and fracture stress $\left(\sigma_{\mathrm{F}}\right)$ of polycarbonate resin sample at different electron beam irradiation dose, together with $\sigma_{\mathrm{U}}$ of irradiated part.

MGy 電子線照射において最大值を示した。0.02 MGy 以下 の低電子線照射線量に打いて延性は向上することが分かっ た，一方，最大值を越える過剩な電子線照射により破断ひず みは低下し，0.2 MGy 以上の照射量に抢ける值は照射前の 值以下になることを確認した。

\section{3 ダングリングボンドの評価}

一般に電子線照射処理はポリマーの重合・架橋，さらに， 分解する場合がある．本電子線照射処理は，結合が切れダン グリングボンドが生成することが推定できる4).そのため, ESR 測定を行いポリカーボネート樹脂中のダングリングボ ンドの有無について検討した. Fig. 6 に電子線照射前後によ るESR スペクトルの変化を示す．この図より, 電子線照射 前のポリカーボネート樹脂ではダングリングボンドの生成を 確認できなかった，一方，電子線照射処理により ESR スペ クトルのピークを確認した。 このことから, 電子線照射によ りダングリングボンドが生成することを確認した.

\section{4. 考察}

\section{1 延性の増大と引張強度の増大のメカニズム}

Fig. 7 に，電子線照射処理による高分子材料のビッカース 硬さの変化を示す8). 一般に柔らかい高分子材料は, 電子線 照射処理を施しダングリングボンドが生成したと仮定して も, 元々が応力緩和されやすいため, 延性の増大や強度の増 大は起こらない.さらに過剩に結合が切断されることから， 延性, 強度は減少するとされる。このことは以前より, 低密 度ポリエチレンの電子線照射処理による硬さの低下ですでに 確認している8). 一方で，ポリカーボネート樹脂は硬い高分 子材料で, 分子間の結合強度が高く, タイトな高分子材料の 構造をもっている.このような材料は変形による応力緩和が 小さく, 比較的延性が低い可能性が高い，そのため, 電子線

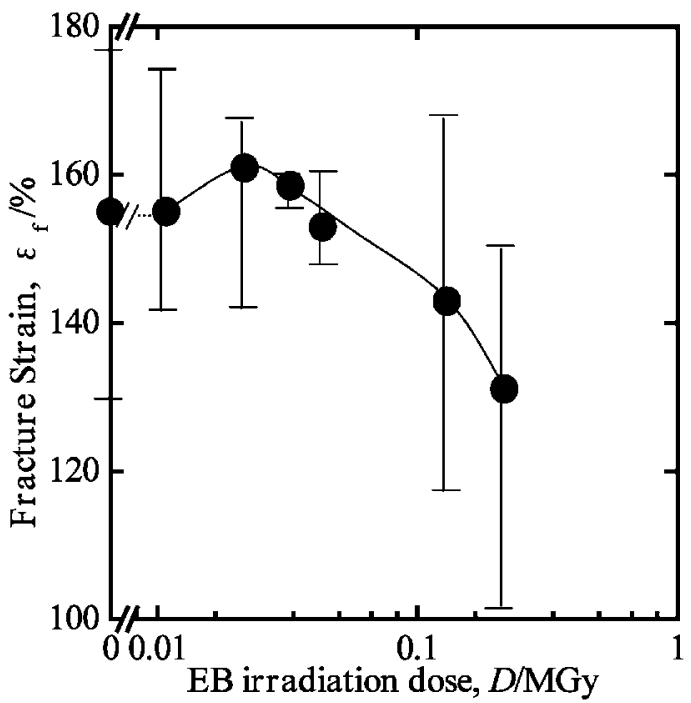

Fig. 5 Change in fracture strain of polycarbonate resin at different electron beam irradiation dose.

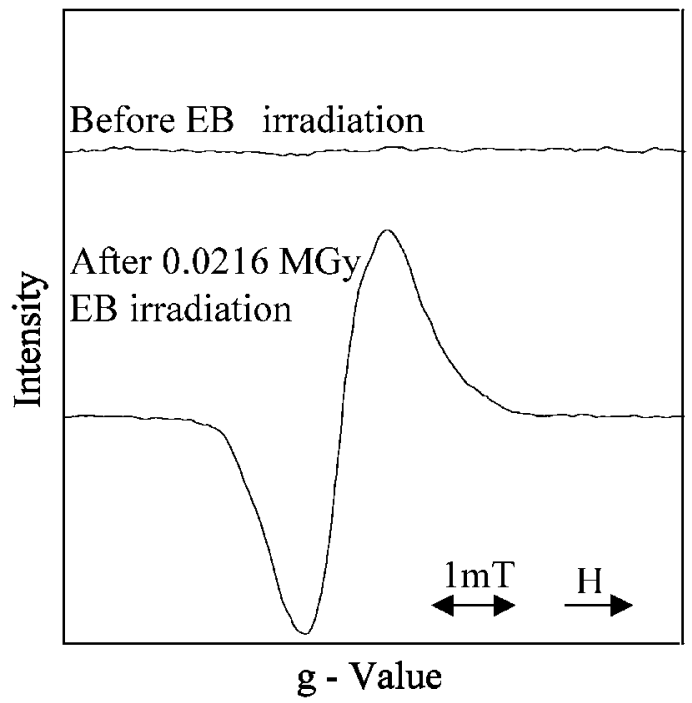

Fig. 6 ESR signals of polycarbonate resin before and after 0.0216 MGy electron beam irradiation.

未照射において応力緩和の効果が大きく硬化する。すなわ ち, この試料に電子線照射処理を施すとダングリングボンド が生成し, タイトな高分子材料の構造の物質に適度な応力緩 和が生じると仮定すると, 分子間の結合は切れにくく破断せ ず伸びるため，延性が向上したことが説明できる.

さらに, 電子線照射により破断応力が向上する現象に関し ても，硬い高分子材料に打いてタイトな高分子材料の構造に 電子線照射処理を施すことにより発生するダングリングボン ドの生成に伴う応力緩和が生じ, クラックの発生や成長を抑 制し, 結果として引張破壊強度が向上すると説明した.

一方，電子線照射により降伏点が向上する現象に関しては ダングリングボンドによる応力緩和により説明可能である. すなわち，ポテンシャルカーブで最も安定な分子間距離(位 置)が応力緩和により変化する可能性が高い，すなわち, 電 子線照射により結合力も高くなるため, 降伏点が高まると考 


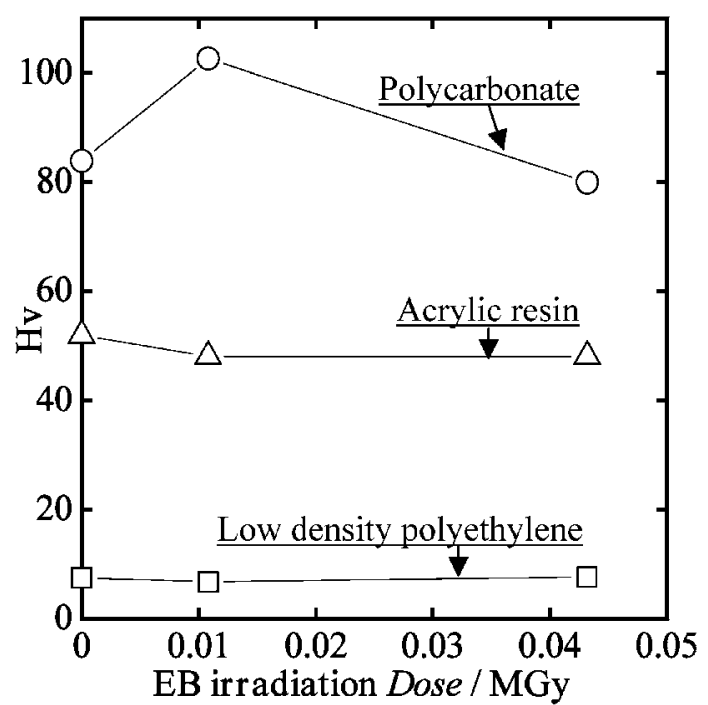

Fig. 7 Vickers hardness (Hv) changes against irradiation dose of polycarbonate (PC), acrylic resin (PMMA) and low density polyethylene (LDPE).

察した.

このことから適度に電子線照射されると, 最適な応力緩和 により延性が向上し，ポテンシャルカーブに抢ける理想的な 位置に近い分子配置により高分子材料の構造が安定するため に結合力は強くなり，ポリカーボネートの強度が向上すると 考察した。

一方，適度に緩和されていた高分子材料の構造は過剩の電 子線照射により結合がさらに多く切断されるために高分子材 料の構造が破壊され，延性が低下し，強度も低下すると説明 した.

\section{2 複合則を用いた照射部分の強度変化}

本研究では, 電子線照射処理は, ポリカーボネート樹脂の 表面層のみに照射されている状態である，そこで複合則を用 いて，ポリカーボネート樹脂が完全に電子線照射処理されて いる場合に抢ける強度変化について考察を行った．複合則に よる応力, 歪及の算出は式 $(2)$ 上り行った.

$$
\sigma(\varepsilon)=X_{\mathrm{EB}} /\left(X_{\mathrm{EB}}+X_{0}\right) \sigma_{\mathrm{EB}}(\varepsilon)+X_{\mathrm{S}} /\left(X_{\mathrm{EB}}+X_{0}\right) \sigma_{0}(\varepsilon)
$$

Fig. 8 に複合則を用いて算出した完全に電子線照射された ポリカーボネート樹脂の応力ー歪み曲線を示す，さらに，照 射した部分の上降伏点 $\sigma_{\mathrm{U}}$ を Fig. 8 の最大值から求めた。 $\sigma_{U}$ の電子線照射による変化を Fig. 4 に示す. 照射前の試料に 比べ, $0.0216 \mathrm{MGy}$ 電子線照射した部分の $\sigma_{\mathrm{U}}$ が $40 \%$ 増大し たことを確認した。

\section{5. 結 論}

本研究ではポリカーボネート樹脂に関して電子線照射処理

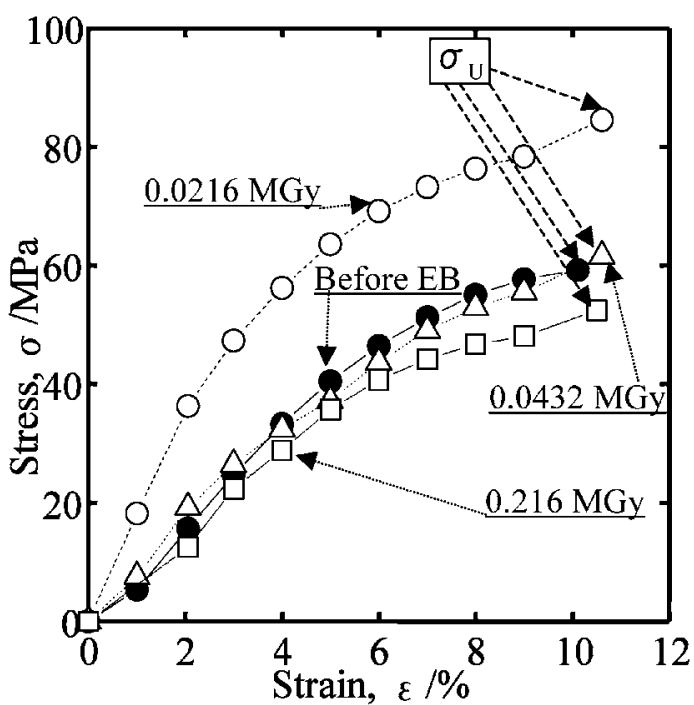

Fig. 8 Estimated stress-strain curves of EB irradiated polycarbonate at different irradiation dose.

を行い，その応力ー歪み曲線への影響について検討を行っ た. その結果, 電子線照射処理による引張強度の向上を確認 した. $0.02 \mathrm{MGy} の$ 電子線照射量で最大值を示すことを見出 した．応力と同じように電子線照射により破断ひずみが増大 し, $0.02 \mathrm{MGy}$ の電子線照射に扔いて最大值を示した.さら に，これを説明するために ESR 測定を行った。この結果, 電子線照射によりダングリングボンドの生成を確認した．以 上の結果より, ポリカーボネート樹脂は電子線照射による化 学的表面改質だけではなく, 機械的性質においても有効なプ ロセスであることを見出した．

引張試験を指導した東海大学工学部の井上恵介修士, 電子 線照射装置の指導を受けた東海大学理学部の利根川 昭助教 授に感謝の意を表する.

\section{文献}

1) Y. Nishi, A. Mizutani, A. Kimura, T. Toriyama, K. Oguri and A. Tonegawa: J. Mater. Sci. 38(2003) 89-92.

2) Y. Nishi, N. Uchida, A. Kimura, A. Mizutani, K.Oguri and A. Tonegawa: J. Mater. Sci. 38(2003) 2215-2218.

3) A. Mizutani, N. Motai, K. Oguri, A. Tonegawa and Y. Nishi: J. Jan. Inst. Met. 67 (2003) 201-204.

4) N. Yamaguti, K. Oguri, A. Tonegawa and Y. Nishi: J. Jan. Inst. Met. 68(2004) 198-201.

5) K. Oguri and Y. Nishi: Materials Transactions. 45(2004) 13461349.

6) K. Oguri, T. Takahashi, A. Kadowaki, A. Tonegawa and Y. Nishi: J. Jan. Inst. Met. 68(2004) 537-539.

7) R. Christenhusz and L. Reimer: Z. angew. Phus. (1967) 397-404.

8) T. Takahashi, K. Oguri, A. Tonegawa and Y. Nishi: Proceedings of SPIE, (Society of Photo-Optical Instrumentation Engineers) 5648 (2004) pp. 345-350. 